\title{
Towards a de-carbonized energy system in north-eastern Morocco: Prospective geothermal resource
}

\author{
Abdelkrim Rimi ${ }^{\mathrm{a}, *}$, Yassine Zarhloule $^{\mathrm{b}}$, Alae Eddine Barkaoui $^{\mathrm{b}}$, Antonio Correia ${ }^{\mathrm{c}}$, \\ Julio Carneiro ${ }^{c}$, Massimo Verdoya ${ }^{\mathrm{d}}$, Francis Lucazeau ${ }^{\mathrm{e}}$ \\ a Institut Scientifique, Université Mohammed V-Agdal, Avenue Ibn Battouta, B.P. 703 Rabat, 10106 Morocco \\ b Université Mohammed 1er, Oujda, Morocco \\ ' Geophysical Centre of Evora (CGE), University of Evora, Portugal \\ d Dipartimento per lo Studio del Territorio e delle sue Risorse, Università di Genova, Italy \\ e Institut de Physique du Globe de Paris, France
}

\section{A R T I C L E I N F O}

\section{Article history:}

Received 22 April 2011

Accepted 19 December 2011

\section{Keywords:}

Geothermal gradient

Heat flow

Thermal spring

Geothermometer

Geothermal potential

Morocco

\begin{abstract}
A B S T R A C T
Geothermal data has been indicating promising potentialities in the north-eastern Morocco. This paper presents new temperature data, recently recorded in water boreholes located in the Berkane and Oujda areas. Generally, the observed temperature gradients are rather high. One hole near Berkane, revealed an average geothermal gradient of more than $110^{\circ} \mathrm{C} / \mathrm{km}$ at depths greater than $300 \mathrm{~m}$. This result confirms the geothermal gradient estimated in a mining borehole located about $30 \mathrm{~km}$ west of the Berkane borehole, in which water temperature of $96^{\circ} \mathrm{C}$ is reached at a depth of about $700 \mathrm{~m}$. Such a high geothermal gradient, exceeding by far the ones already determined for northeastern Morocco, could act as a stimulus to programs aimed at the geothermal exploitation of high temperature aquifers.
\end{abstract}

(c) 2012 Elsevier Ltd. All rights reserved.

\section{Contents}

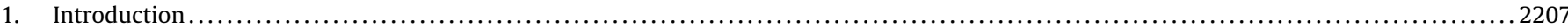

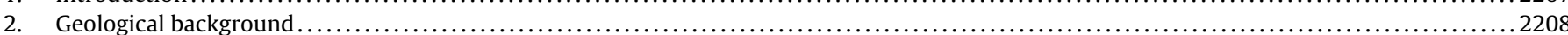

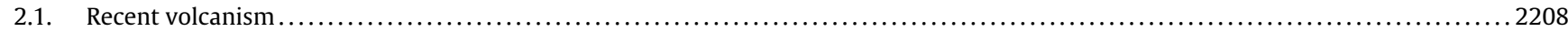

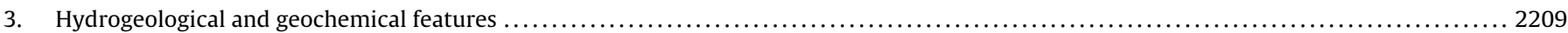

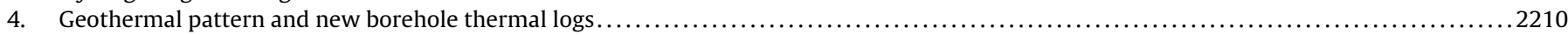

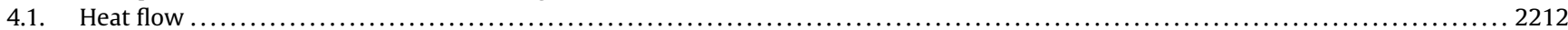

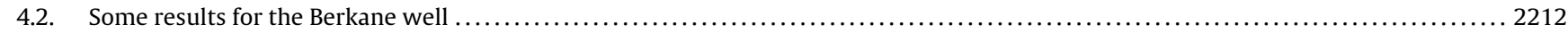

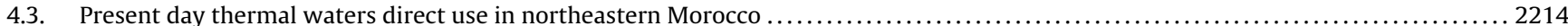

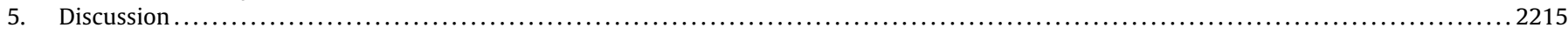

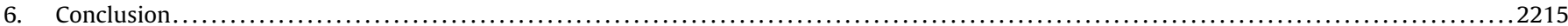

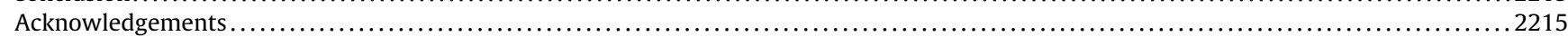

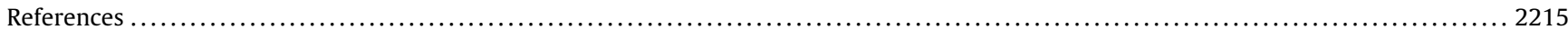

\section{Introduction}

Since 2009, Morocco has been engaged in a sustainable development and renewable energy strategy. With no oil reserves Morocco has the necessary assets to achieve these goals, particularly of developing free carbon energies, mainly solar, wind and geothermal. Owing to its special geographical and geological position, North East part of Morocco, which is endowed by a natural bounty

\footnotetext{
* Corresponding author.

E-mail addresses: rimikrimo@gmail.com, rimi@israbat.ac.ma (A. Rimi).
}

of sunshine and geothermal resources, has seen a number of starting projects including that of the solar thermal plant of Ain Bni Mathar. This paper we will focus particularly on its geothermal potential, which may reinforce its development as an emerging economic region.

Since Rimi and Lucazeau [1] have been pointed out the regional thermal phenomena (volcanism, hot springs, extensive tectonics and seismic activity) in North-eastern Morocco, most advanced temperature and geochemical sampling have been done in this part of Morocco [2,3]. Work accomplished in this region has highlighted the opportunity for large-scale geothermal anomaly from deep [4], 
while several southern Morocco sedimentary basins such as the Souss Coastal Basins are now being explored for lower enthalpy. Both subsectors have been inferred to contain enormous quantities of stored heat $[5,6]$. Due to the large number and size of surface thermal manifestations (hot springs, recent volcanism and neotectonic activity), north-eastern Morocco is a region that has attracted the attention of geothermal experts since the 1960s [7-9].

\section{Geological background}

Eastern Morocco is a system of plains, plateaus and mountain ranges extending on the eastern parts of the Meseta-Atlas and Rif domains. It is represented by the Eastern Middle Atlas that continues through the Guercif basin to Beni Snassen, the valley of Moulouya, the Oujda-Taza corridor, the "Pays des Horsts" and a crustal block without notable alpine deformation, which constitutes the High Plateaus. Three ENE-WSW structural units are defined in Eastern Morocco region Fig. 1:

- The eastern-rifian foreland composed of Gareb chaotic unit near the active Rif chain and a little deformed tectonic foreland (Terni Masgout, Beni Bou Yahi, Beni Mamou and Beni Snassen), prolonged towards the east (in Algeria) by the Traras mounts.

- The Guercif and Taourirt-Oujda basins which show sediments of middle Miocene to Quaternary age, and are connected to the Tafna basin to the east (Algeria).

- The Taourirt-Oujda mounts which show sub-horizontal Jurassic sediments affected by fault systems whose development and geometry are strongly dependent on the pre-existing structures in hercynian basement. They are prolonged to the east by the pre-tellian foreland of Tlemcen.
The Rif domain, located northwards, belongs to the Betic-Rif belt and is part of the peri-Mediterranean alpine chain. With the Atlas, these morpho-structural zones result from the superposition of several tectonic, compressive and extensional phases of alpine age.

These phases have occurred since the Late Cretaceous. Most of these zones are ENE-WSW to E-W directed (e.g., "Pays des Horsts") and NE-SW (Middle Atlas, valley of Moulouya), reflecting part of the alpine geological evolution.

From Landsat image analysis, El Hammichi et al. [10] had depicted four faults systems:

(a) The first system, NE-SW oriented, is well developed and represented by several faults with regional importance. Along this fault, structures are very clear and indicate prevailing left strike-slip movement;

(b) $\mathrm{NW}-\mathrm{SE}\left(\mathrm{N} 135^{\circ} \mathrm{E}\right.$ to $\left.\mathrm{N} 160^{\circ} \mathrm{E}\right)$ trending faults are often longer than $15 \mathrm{~km}$ and extend the southern sector;

(c) The third system in this sector is represented by arcuate ENE-WSW to E-W trending faults;

(d) The last fault system, affecting especially the western side of the studied area, is represented by faults trending $\mathrm{N}-\mathrm{S}$. These faults are clear and long lineaments. Kinematic indicators and vertical offsets testify normal movements.

\subsection{Recent volcanism}

On the scale of Morocco, the volcanic centers extend roughly along a NE-SW direction since the Mediterranean coast to the AntiAtlas and the Canary Islands.

In North eastern Morocco, late Miocene to Pliocene volcanic activities correspond to a shoshonitic edifices in the Guilliz and

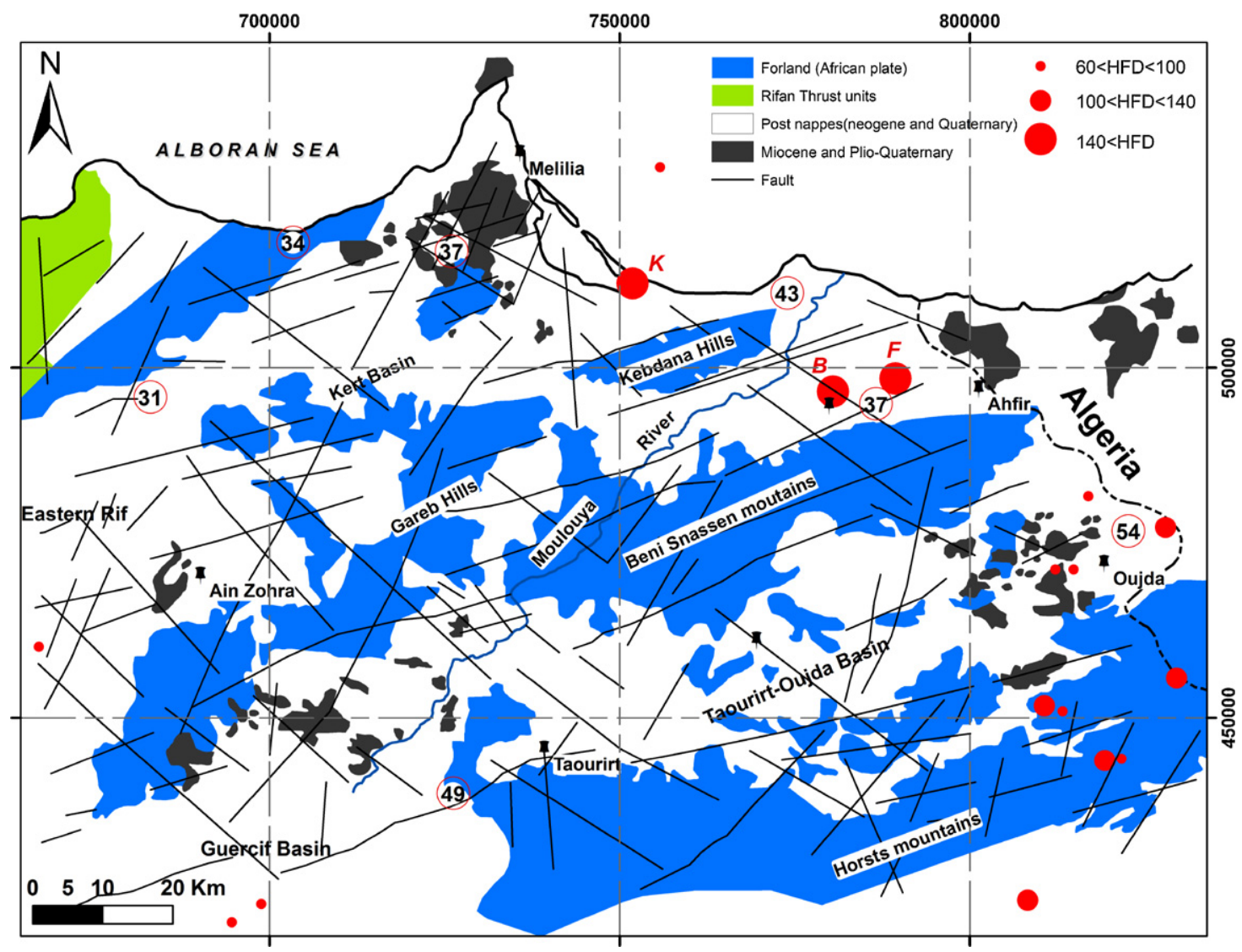

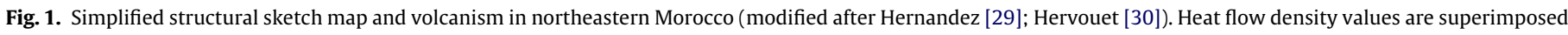
on this map; numbers in circle represent spring temperature values, $K$ : mining borehole at Kariat Arekman, $B$ : borehole at Berkane and $F$ : borehole at Fezouane site. 
Koudiat Hamra (near Taourirt) (Fig. 1) with age ranging from 8 to $4.5 \mathrm{My}$ [11] and calcalkaline centers in the Oujda area (Fig. 1) with age ranging from 6.2 to $4.8 \mathrm{My}$ [12].

Regionally, the study area is located east of Gibraltar Arc, which is currently the subject of many geological, geophysical and geodynamical investigations. This has shown that the Gibraltar Arc is characterized by thinned crust and lithosphere, with a fast thickening towards the Betics and the Rif mountain ranges.

In eastern Morocco, magmatism developed during the Miocene. A more recent episode consisting of alkaline volcanic activity has taken place from 6 to $0.8 \mathrm{Ma}$, and occurred along a NE-trending belt extending from the Trans-Alboran zone to the Middle Atlas domain and to the Anti-Atlas (J. Siroua volcano). Their geochemical signature is similar to that of intra-oceanic island basalts, and suggests the role of an asthenospheric "hot lineament" [13]. Such interpretation is consistent with gravimetric and geodetic modeling of the lithosphere [14-16]. This MHL could extend from the Canary Islands to southeast Spain at least.

Lithospheric thinning under the Alboran Sea and thickening under two ridges of the adjacent Gibraltar Arc is of basic importance for geodynamic models which invoke convective removal and orogenetic collapse, a mantellic delamination and an active subduction [17-21]. The Alboran Sea continues eastward with the Algerian oceanic crust basin [22].

\section{Hydrogeological and geochemical features}

A sub-surface reservoir is suitable for extracting heat, if its porosity, permeability, thickness, lateral extension and temperatures are sufficiently large. For a preliminary description of the geothermal areas of Morocco, two criteria are considered:
- The structural, lithological and hydrogeological context to establish the existence or the absence of aquifers;

- Temperatures of aquifers, or impermeable formations up to $3 \mathrm{~km}$ deep.

The variety of tectonic and lithostratigraphic in Morocco has created various hydrogeothermal systems with heterogeneous lithological and physical properties. Regional studies in Prerif [23], eastern Morocco [24], the plateau of phosphates [25], EssaouiraAgadir Basin [26,27] and the central Morocco [28] have been gathering background information on aquifers from archives of piezometers and oil Boreholes: structure, depth, porosity, modflow and groundwater velocity.

But features such as permeability, transmissivity and salinity are often lacking. According to these studies, the potential geothermal aquifers resources in Morocco are of two types:

(1) In the latest Tertiary and Quaternary deposits, water pumped out from pore spaces during compaction could constitute up to $700 \mathrm{~m}$ depth, aquifers of good low temperature $\left(50-60^{\circ} \mathrm{C}\right)$.

(2) The typical system of water circulation for pre-Tertiary aquifers, $1000-4000 \mathrm{~m}$ depth, is guided by differences in hydraulic load associated with formation changes. The meteoric water infiltrates into the hills and topographic relief and discharges in areas of low groundwater level, mainly in Mesozoic carbonates of the major basins. If the permeabilities are favorable, the water can penetrate deep enough and warm up gradually (average temperature is $100^{\circ} \mathrm{C}$ ). However, the lithological nature may lead to the formation of local or even regional convective systems. The descent of cold water and the rise of hot water can disturb the thermal field.

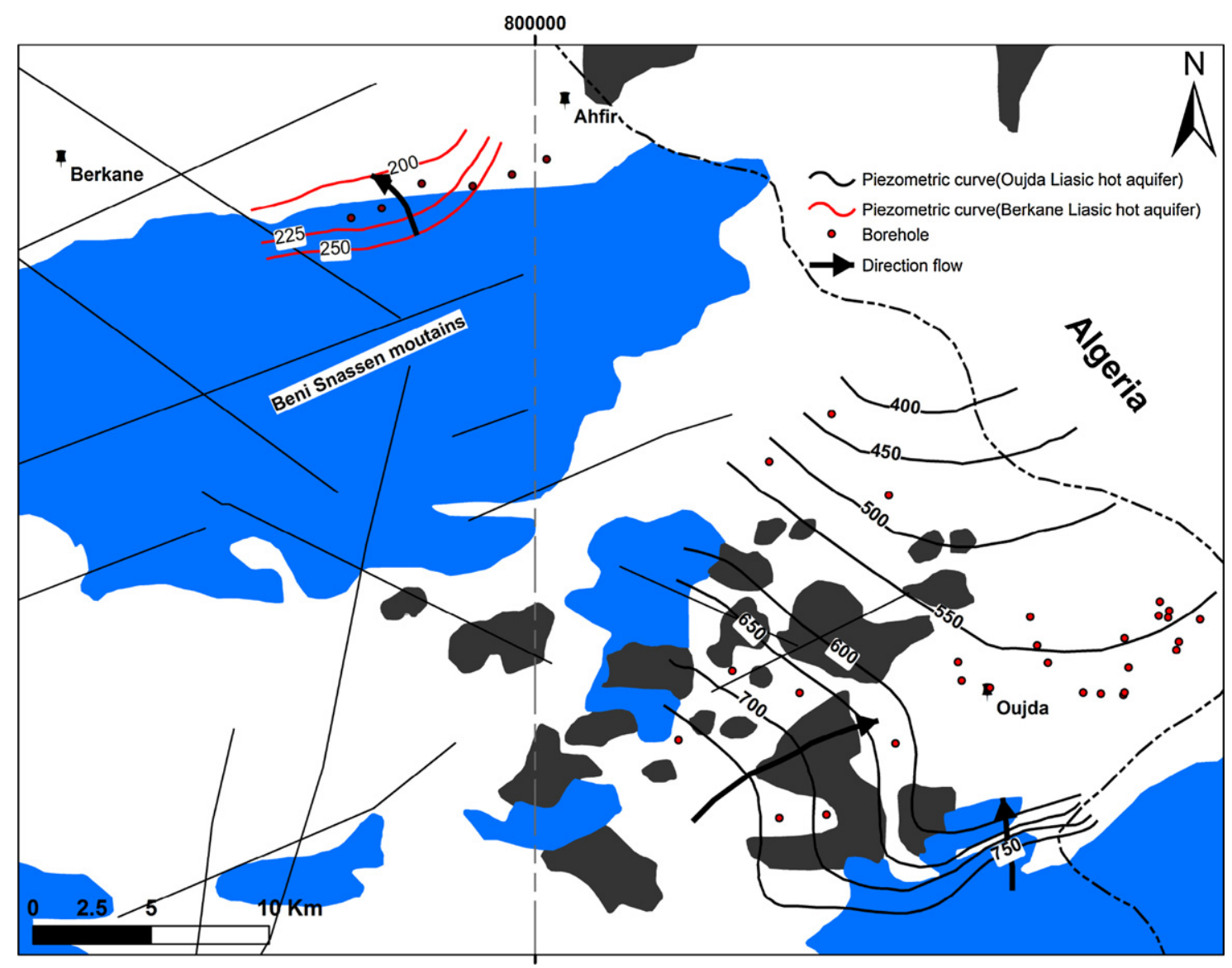

Fig. 2. Oujda and Berkane Liassic aquifer [4]. 
Table 1

Thermal data from hydrogeological and petroleum boreholes.

\begin{tabular}{|c|c|c|c|c|c|c|}
\hline Descriptives codes & Latitude & Longitude & $\begin{array}{l}\text { Elevation } \\
(\mathrm{m})\end{array}$ & $\begin{array}{l}\text { Maximum depth } \\
(\mathrm{m})\end{array}$ & $\begin{array}{l}\text { Geothermal gradient } \\
\left({ }^{\circ} \mathrm{C} / \mathrm{Km}\right)\end{array}$ & $\begin{array}{l}\text { Heat flow } \\
\left(\mathrm{mW} / \mathrm{m}^{2}\right)\end{array}$ \\
\hline Fezouane2 & 34.927 & -2.213 & 252 & & 49.0 & 140 \\
\hline 1624/7 Berkane & 34.93 & -2.3 & 160 & & 127.0 & $510^{*}$ \\
\hline $2952 / 12$ & 34.693 & -1.818 & 560 & 500 & 49.0 & 111 \\
\hline $2362 / 12$ & 34.647 & -1.930 & & 215 & 43.0 & 87 \\
\hline $1199 / 12$ & 34.645 & -1.964 & 641 & 125 & 34.0 & 90 \\
\hline $1225 / 12$ & 34.782 & -1.930 & & 75 & 49.0 & 98 \\
\hline $2899 / 12$ & 34.642 & -1.847 & 620 & 128 & 14.0 & 89 \\
\hline $186 / 16$ & 34.015 & -1.913 & 385 & 255 & 32.0 & 60 \\
\hline A 4 & 34.305 & -2.227 & 1068 & 260 & 39.0 & 81 \\
\hline A 13 & 34.311 & -2.232 & 1095 & 170 & 30.0 & 119 \\
\hline A 14 & 34.309 & -2.238 & 1068 & 350 & 34.0 & 100 \\
\hline A 7 & 34.299 & -2.222 & & 216 & 36.0 & 89 \\
\hline P 3 & 34.308 & -2.232 & & 240 & 33.0 & 68 \\
\hline BR41W & 34.45 & -1.802 & 1058 & 170 & 45.0 & 144 \\
\hline TEFADIS & 34.507 & -1.780 & 1125 & 100 & 45.0 & 112 \\
\hline BN38NW & 34.452 & -1.81 & 1053 & 100 & 43.0 & 105 \\
\hline BN30 & 34.443 & -1.792 & 1050 & 120 & 37.0 & 108 \\
\hline BS38N & 34.450 & -1.804 & & 120 & 36.0 & 84 \\
\hline BR41S & 34.448 & -1.807 & & 120 & 35.0 & 91 \\
\hline NADOR1 & 35.326 & -2.662 & & 2703 & 41.8 & 86 \\
\hline AREKMAN & 35.109 & -2.739 & & 678.7 & 124.0 & 192 \\
\hline YADIM & 35.093 & -2.475 & 70 & 40 & 57 & \\
\hline Grf1 & 34.279 & -3.424 & & & 36.3 & 92 \\
\hline Tafrata1x & 34.22 & -3.106 & & & 34.6 & 76 \\
\hline Msd1 & 34.245 & -3.47 & & & 37.0 & 90 \\
\hline
\end{tabular}

${ }^{*}$ This value is still a rough estimate since we have no real determination of thermal conductivity and porosity. Ranging from 3.7 to $5.5 \mathrm{~W} / \mathrm{m}{ }^{\circ} \mathrm{C}$, the thermal conductivity of the dolomite decreases as the porosity and temperature increase.

For an area to be prospective for high enthalpy geothermal resource there must exist high average geothermal gradients to create high temperatures at depths over a significant area which can be economically drilled. In addition to this the heat must be able to be economically exploited. This requires the existence of suitable reservoir rocks with either high natural porosity and permeability or the conditions that allow permeability to be artificially enhanced by reservoir engineering.

The sedimentary formations in north-eastern Morocco units contain hot reservoirs; in particular Liassic carbonates up to $500 \mathrm{~m}$ thick which is the most important aquifer in the region (Fig. 2). The main aquifer is fed into the Horsts area and discharges in the plain of Oujda-Angad, and is composed of carbonate rocks (limestones and dolomites) from the lower Cretaceous, the Lias (Fig. 2). The isobaths of Lias vary from a few meters south to $1000 \mathrm{~m}$ towards the north. Hydrostratigraphic studies based on geological and hydrogeological data from boreholes show the Liassic carbonate to be the main hydrogeothermal reservoir of the hot springs in the region.

The Liassic reservoir of Eastern Morocco belongs to the Atlas domain, which is characterized by a succession of NE-SW horst and graben of pre-Miocene age and by Plio-quaternary basaltic volcanics, associated with crustal thinning (Table 1 ).

This reservoir is at the origin of twenty-four thermal springs. Table 2 whose temperature ranges from 20 to $54{ }^{\circ} \mathrm{C}$ and the flow rate can reach $40 \mathrm{l} / \mathrm{s}$ at certain points. Salinity varies from 0.28 to $29.6 \mathrm{~g} / \mathrm{l}$. Some of these hot springs play an important role in the economy of the area (e.g., Fezouane, near Berkane and Hammam Ben Kachour, at Oujda [3,4].

Fig. 2 shows the Liassic aquifer in both Oujda and Berkane region. The piezometrical map shows that flow direction is from SE to NW. The recharge area of the confined aquifer is localised in the south, where the Liassic outcrops. In the Fezouane region, the aquifer is artesian.

In the Oujda region, the Liassic limestone forms the main aquifer. Limestone outcrops in Beni Snassen, High-Atlas, Middle-Atlas and the southern part of the basin. The thickness varies from $50 \mathrm{~m}$ to $1140 \mathrm{~m}$, and the maximum depth is $1370 \mathrm{~m}$. The groundwater flow is from south to north of basin Fig. 2 . The aquifer temperature and salinity vary from $20^{\circ} \mathrm{C}$ to $52^{\circ} \mathrm{C}$ and from $130 \mathrm{mg} / \mathrm{l}$ to $3000 \mathrm{mg} / \mathrm{l}$, respectively.

According to Zarhloule [3], the hot temperature and the artesian rise of most of the thermal springs in north-eastern Morocco originate from deep circulation in relation to a system of basement active faults, individuating horsts and grabens, in a recent volcanic area.

Winckel [28] performed a thorough geochemical analysis of the main hot springs in Morocco and found that eleven of those located along the MHL (Moroccan Hot Line) release $\mathrm{CO}_{2}$ that is partially of deep origin. Recently, Tassi et al. [31] confirmed that $\mathrm{CO}_{2}$-rich thermal springs with $3 \mathrm{He}$ anomalies are likely related to this hot line. They are mainly distributed along a NE-SW trend from Nador to Taza, and from Fes (Moulay Yacoub) to Oulmes south of the Rif frontal thrust. The contemporary presence of $3 \mathrm{He}$ anomalies and minor recent basalt outcrops indicate that $\mathrm{CO}_{2}$ originates from mantle degassing or deep hydrothermal systems in these thermal discharges

The geochemical analyses and water classification by means of the diagram of Langelier and Ludwig gave the following hydrogeochemical facies $\left.\mathrm{Ca}(\mathrm{Mg})-\mathrm{HCO}_{3}\right), \mathrm{NaCl}$ and $\mathrm{Ca}-\mathrm{Mg}[6]$.

The estimated temperatures by silica geothermometers vary between 37 and $85^{\circ} \mathrm{C}$ (quartz of Fournier), 23 and $73^{\circ} \mathrm{C}$ (quartz of Arnorsson), $54^{\circ} \mathrm{C}$ (chalcedony of Fournier) and $57^{\circ} \mathrm{C}$ (chalcedony of Arnorsson). The measured emergence temperatures vary between 20 and $54{ }^{\circ} \mathrm{C}$. The correction of the water estimated reservoir temperatures by the mixture geothermometer reveals that the temperature in the original reservoir may exceed $110^{\circ} \mathrm{C}$, with a relatively low rate of mixture between hot deep water and cold surface water.

\section{Geothermal pattern and new borehole thermal logs}

Hydrogeothermal structure was impulsed by a geothermal anomaly measured in a mining borehole drilled in rhyolitic and andesitic series at Kariat Arekman $\left(35.11^{\circ} \mathrm{N}, 2.74^{\circ} \mathrm{W}\right.$; Fig. 3). The well, $680 \mathrm{~m}$ deep, revealed from $450 \mathrm{~m}$ depth salt artesian water (20-25 g/l and a flow rate of $1.4-21 / \mathrm{s})$ with a temperature of 
Table 2

Thermal springs properties.

\begin{tabular}{|c|c|c|c|c|c|c|c|c|c|}
\hline Name & Latitude & Longitude & $T\left({ }^{\circ} \mathrm{C}\right)$ & $\begin{array}{l}\text { Rate } \\
(1 / s)\end{array}$ & Gas & Chimical Facies & Reservoir & Use & Project \\
\hline $\begin{array}{l}\text { Sidi chaffi } \\
\text { Midar }\end{array}$ & 34.9 & -3.61 & 32 & 4 & $\mathrm{CO}_{2}$ & $\mathrm{Na}-\mathrm{HCO}_{3}$ & $\begin{array}{l}\text { Marl-limestone } \\
\text { cretaceous }\end{array}$ & $\begin{array}{l}\text { Drink, therapeutic } \\
\text { bathing, irrigation }\end{array}$ & Hammam \\
\hline Ain Messouda & 35.03 & -3.25 & $17-21$ & 3 & & $\begin{array}{l}\text { Chloride, sodium, } \\
\text { sulfate, } \\
\text { calcic-magnesian }\end{array}$ & & $\begin{array}{l}\text { Gastric and urinary } \\
\text { diseases }\end{array}$ & $\begin{array}{l}\text { Botling } \\
\text { manufactory } \\
\text { project in } 1959\end{array}$ \\
\hline $\begin{array}{l}\text { Ain Hammam } \\
\text { Beni Sidel }\end{array}$ & 35.17 & -3.19 & $32-35$ & 1 & $\mathrm{H}_{2} \mathrm{~S}, \mathrm{CO}_{2}$ & $\mathrm{Na}-\mathrm{Cl}$ & $\begin{array}{l}\text { Miocene rhyolite } \\
\text { post nappe, Tuffs et } \\
\text { breccias } \\
\text { interbedded }\end{array}$ & $\begin{array}{l}\text { Dermatological } \\
\text { bathings }\end{array}$ & Hammam \\
\hline $\begin{array}{l}\text { Hammam } \\
\text { Chaabi }\end{array}$ & 35.17 & -3.09 & 34 & 2 & & $\mathrm{Na}-\mathrm{Cl}$ & $\begin{array}{l}\text { Massive limestone } \\
\text { and gray slate of } \\
\text { Jurassic of } \\
\text { Taliouîne }\end{array}$ & $\begin{array}{l}\text { Dermatological } \\
\text { bathings }\end{array}$ & Hammam \\
\hline Hajra Safra & 34.26 & -3.56 & & 2 & $\mathrm{CO}_{2}$ & $\mathrm{Na}-\mathrm{Cl}$ & $\begin{array}{l}\text { Marl-limestone } \\
\text { cretaceous } \\
\text { miocene }\end{array}$ & $\begin{array}{l}\text { Dermatological } \\
\text { bathings }\end{array}$ & Hammam \\
\hline $\begin{array}{l}\text { Ain Haddou Ou } \\
\text { Hamma }\end{array}$ & 35.14 & -3.09 & 29 & 1 & $\mathrm{H}_{2} \mathrm{~S}, \mathrm{CO}_{2}$ & $\mathrm{Na}-\mathrm{Cl}$ & $\begin{array}{l}\text { Massive limestone } \\
\text { and gray slate of } \\
\text { Jurassic of } \\
\text { Taliouîne }\end{array}$ & $\begin{array}{l}\text { Dermatological } \\
\text { bathings }\end{array}$ & Hammam \\
\hline Ain Goutitir & 34.35 & -3.06 & $44-49$ & 12 & & $\mathrm{Cl}-\mathrm{Ca}$ & $\begin{array}{l}\text { Limestone- } \\
\text { dolomitic lower } \\
\text { lias-Domerian }\end{array}$ & Hydrotherapy & Hammam \\
\hline Gufait Springs & 34.24 & -2.38 & 26 & $10-15$ & & $\mathrm{SO}_{4}-\mathrm{Ca}$ & $\begin{array}{l}\text { Limestone- } \\
\text { dolomitic } \\
\text { Lias }\end{array}$ & $\begin{array}{l}\text { Bathing, drink and } \\
\text { irrigation }\end{array}$ & \\
\hline Ain Bourachad & 33.86 & -3.60 & 32 & 2 & & $\mathrm{Na}-\mathrm{Cl}$ & $\begin{array}{l}\text { Limestone- } \\
\text { dolomitic } \\
\text { Lias-Dogger }\end{array}$ & Dermatology & Two pools \\
\hline Ain El Hamra & 34.61 & -3.91 & $24-26$ & $6-15$ & $\mathrm{CO}_{2}$ & $\mathrm{HCO}_{3}-\mathrm{Ca}$ & $\begin{array}{l}\text { Marl-limestone } \\
\text { and sandstone } \\
\text { Miocene }\end{array}$ & $\begin{array}{l}\text { Repute for kidney } \\
\text { diseases }\end{array}$ & Hammam \\
\hline
\end{tabular}

$42{ }^{\circ} \mathrm{C}$ at the surface, and more than $90^{\circ} \mathrm{C}$ at the bottom [32]. This good result infirmed the earlier studies $[8,9]$, which concluded on the base on 60 meters deep thermal profiles, that northeastern Morocco does not constitute really a zone with significant geothermal potential. Carried out in the very shallow boreholes, such works cannot be considered conclusive, because the thermal state is strongly disturbed by water movement at this depth. In addition, more recent deep geophysical investigations (seismological, gravity and magnetic) claim that the positive geothermal anomaly in the Rif and Eastern Morocco is explainable as a surface manifestation of a deep and wide tectono-magmatic lithospheric process [33].

The surface heat flow and broad thermal conductivity structure (and thus the temperature field) of northeastern Morocco has been estimated since 1987, [1,3,4,6] provided broad approximations of northeastern Morocco continent temperature field, but suffered from a sparse geographic distribution of heat flow and thermal conductivity data.

The analysis of the long wavelength anomalies highlights a heat flux increasing northeastward: $80-110 \mathrm{~mW} / \mathrm{m}^{2}$ in the eastern Rif, northeastern Morocco, Alboran Sea (east of the meridian line $4^{\circ} \mathrm{W}$ ), southeastern Spain and northwestern Algeria. In eastern Morocco, the crust is thinned to $15-20 \mathrm{~km}$. The highest heat flow $\left(80-140 \mathrm{~mW} / \mathrm{m}^{2}\right)$ and geothermal gradient $\left(35-50^{\circ} \mathrm{C} / \mathrm{km}\right)$ are observed in the north-eastern part of the country (Middle Atlas and Eastern Rif), which is characterized by intensive Quaternary volcanism, high residual magnetic anomalies and shallow Curie depths [34]. The Gibraltar Arc region is characterized by a radial heat flow pattern with increasing values from the outer ranges towards the center and eastern part of the basin [2,35] (Fig. 4). The most striking geothermal feature is the abnormally hot zone observed east of $4{ }^{\circ} \mathrm{W}$ and the heat flow increase towards the Algerian basin, where we find volcanic environments and high values typical of a young oceanic lithosphere $[2,36]$.
Fig. 5 shows a set of temperature data recorded in boreholes of the study area in 1986 [1]. It shows that the geothermal gradient is generally larger than $30^{\circ} \mathrm{C} / \mathrm{km}$. New thermal logs were performed in 2007 and 2009 at some boreholes (see Fig. 1 for their location). Fig. 6 points out abnormally hot deep geotherms beneath Eastern Rif and Alboran basin [37].

With the objective of improving the geothermal dataset and gaining a better insight into the geothermal potential of eastern Morocco, an exploratory geothermal survey was conducted in 2007 and 2009; in the region of Oujda (Fig. 6) to log some hydraulic boreholes. In particular, two wells in the region of Berkane show high geothermal gradients and could prove valid for high enthalpy geothermal purposes. This paper is a summary of the results of these recent investigations and discusses the new data in the light of previously collected information in deep and shallow boreholes (Fig. 7).

The borehole 2952/12. Fig. 8a shows a good concordance between the thermal profiles measured after 20 years. At $600 \mathrm{~m}$ depth (corresponding to the lithological change from marl to carbonate), the borehole may be invaded with by a warm water arrival. This results in a sharp decreases and even an inversion of the geothermal gradient. The thermal log of the well located $30 \mathrm{~km}$ west of Berkane. Fig. 8b is characterized by an increase of the geothermal gradient at $300 \mathrm{~m}$ depth. Notice that the increase of geothermal gradient cannot, to a certain extent, be explained by a change in lithology. In that case, as dolomite should have thermal conductivity higher than clay, the geothermal gradient should decrease. For the moment, no thermal conductivity measurement is available and no heat flow density estimate can be done.

The thermal log of the Fezouane hole (Fig. 8c) exhibits a thermal gradient, which apparently varied with depth. The thermal gradient is $42^{\circ} \mathrm{C} / \mathrm{km}$ in the uppermost $60-120 \mathrm{~m}$ section, and then decreases to $14{ }^{\circ} \mathrm{C} / \mathrm{km}$ between 120 and $150 \mathrm{~m}$, to increase again to about $70^{\circ} \mathrm{C} / \mathrm{km}$ in the deeper part of the hole. Notice that this 


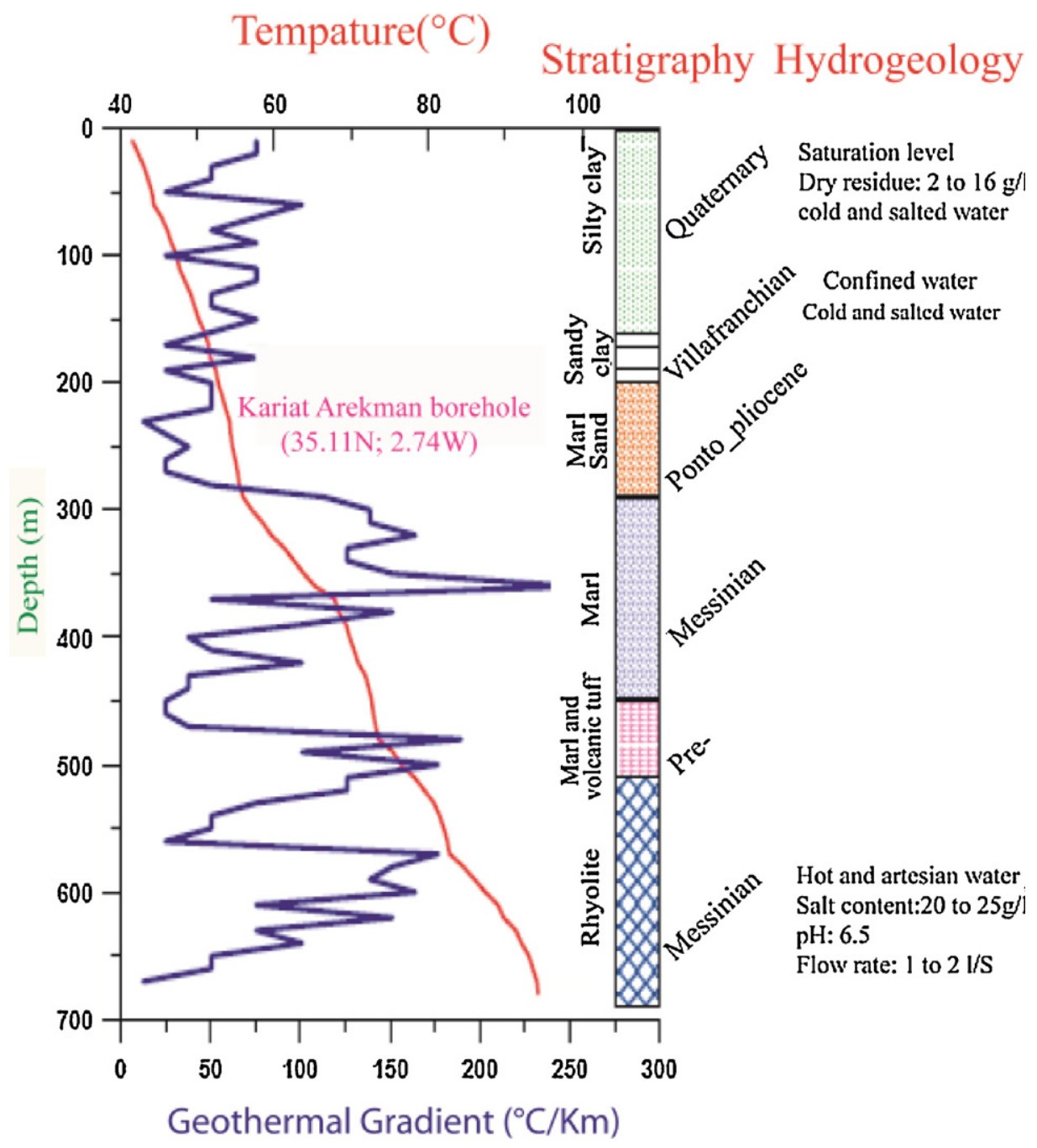

Fig. 3. Observed temperature in the Kariat Arekman hole [32]. Local estimated heat flow density exceeding $200 \mathrm{~mW} / \mathrm{m}^{2}$ [1].

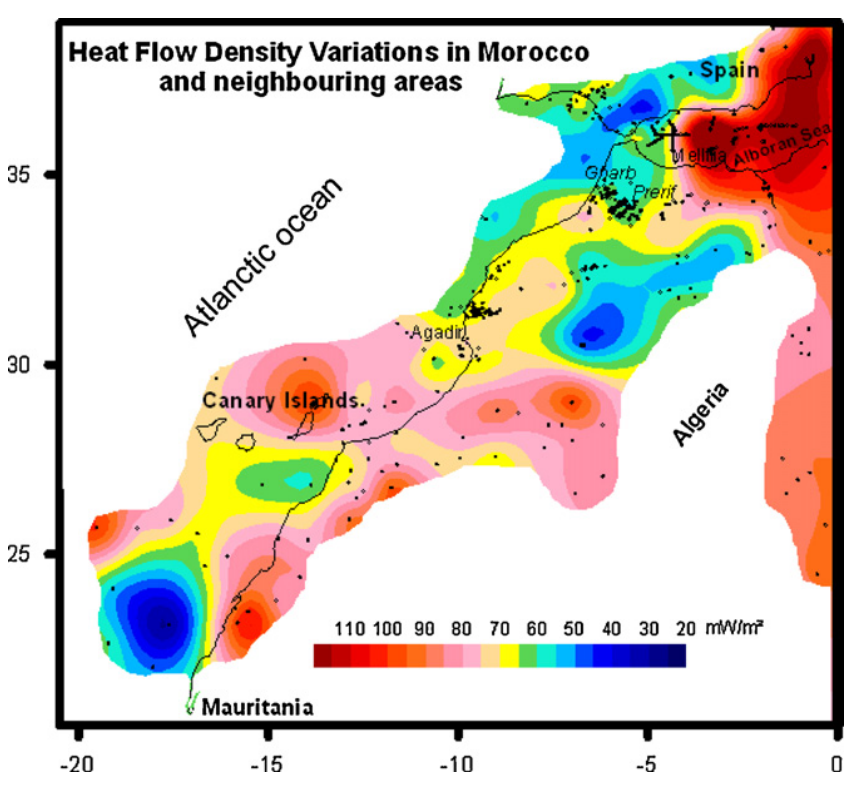

Fig. 4. Terrestrial heat flow density in Morocco and neighboring regions [34]. log is significantly affected by water flowing within the hole, since it crosses a confined, artesian aquifer.

\subsection{Heat flow}

If we assume that the conduction is the main mode of heat transfer in the crust, average vertical heat flow, at the earth's surface can be determined by:

$Q_{S}=\lambda_{z} \operatorname{grad}_{z}+\sum H$

where $\left(z\right.$ is the thermal conductivity $(\mathrm{W} / \mathrm{mK})$ at depth $z$ and $\operatorname{grad}_{z}$ the geothermal gradient $(\mathrm{K} / \mathrm{m})$ at depth $z$, $(H$ is the additive radioactive heat production between the surface and the depth $z$.

\subsection{Some results for the Berkane well}

This change in the geothermal gradient is not a result of a thermal conductivity change. A simple calculation shows that the average geothermal gradient above $300 \mathrm{~m}$ is about $29^{\circ} \mathrm{C} / \mathrm{km}$ $\left(0.0293^{\circ} \mathrm{C} / \mathrm{m}\right)$ while the geothermal gradient below $300 \mathrm{~m}$ is about $127^{\circ} \mathrm{C} / \mathrm{km}\left(0.1275^{\circ} \mathrm{C} / \mathrm{m}\right)$. At a depth of about $470 \mathrm{~m}$ the temperature is $50^{\circ} \mathrm{C}$, and assuming that the same formation reaches depths of $700 \mathrm{~m}$ (see lithologic $\log$ ) this means that an estimated temperature of about $78^{\circ} \mathrm{C}$ is attained at about $700 \mathrm{~m}$.

If we assume a thermal conductivity of $1.5 \mathrm{~W} / \mathrm{mK}$ for the clay above $300 \mathrm{~m}$ and a thermal conductivity of $4.0 \mathrm{~W} / \mathrm{mK}$ for the 


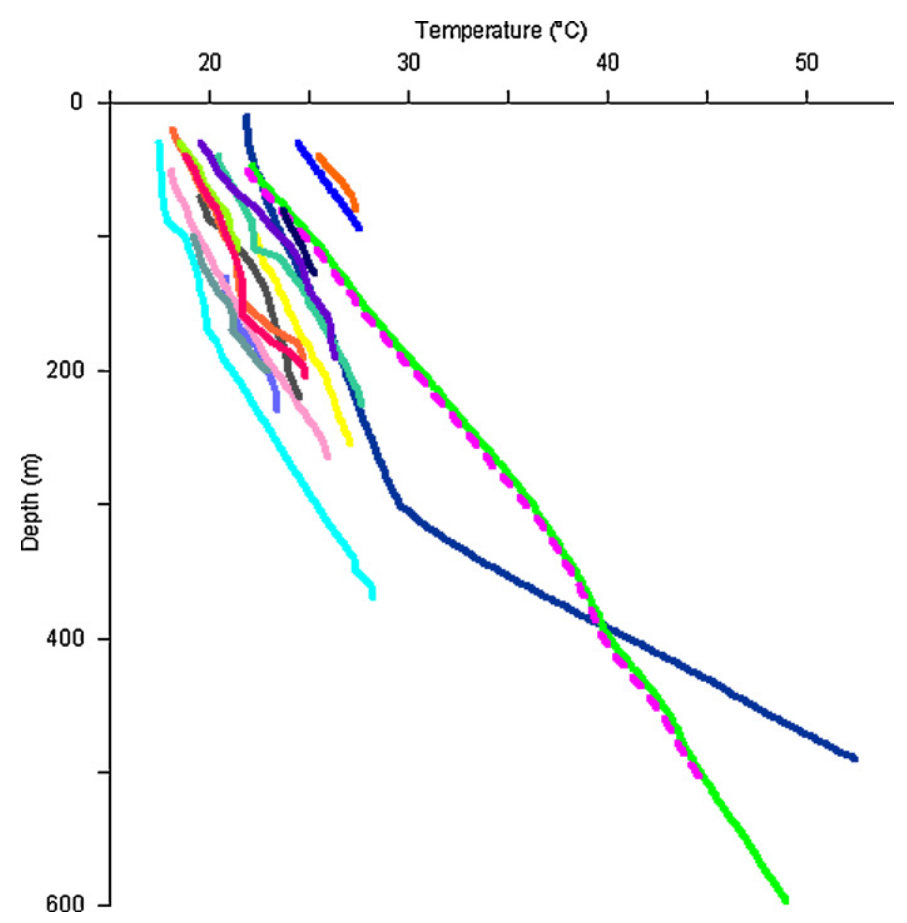

Fig. 5. Thermal profiles in mining and water boreholes done in Oujda-Berkane region.

dolomites below $300 \mathrm{~m}$ we can conclude that the heat flow density (HFD) along the well is not constant and therefore there is geothermal energy trapped for levels below $300 \mathrm{~m}$ deep. The estimated HFD above $300 \mathrm{~m}$ is $43 \mathrm{~mW} / \mathrm{m}^{2}$, and below $300 \mathrm{~m}$ is $510 \mathrm{~mW} / \mathrm{m}^{2}$.

If we assume that the well is representative of the geologic, hydrogeologic, and thermal status for a relatively large are (let's say tens of square $\mathrm{km})$, we can try to estimate the heat in place $\left(H_{0}\right)$ within the aquifer using the following equation:

$H_{0}=\left[(1-\Phi) \rho_{m} C_{m}+\Phi \rho_{w} C_{w}\right] \cdot\left(T_{t}-T_{0}\right) \cdot A \cdot \Delta_{z}$

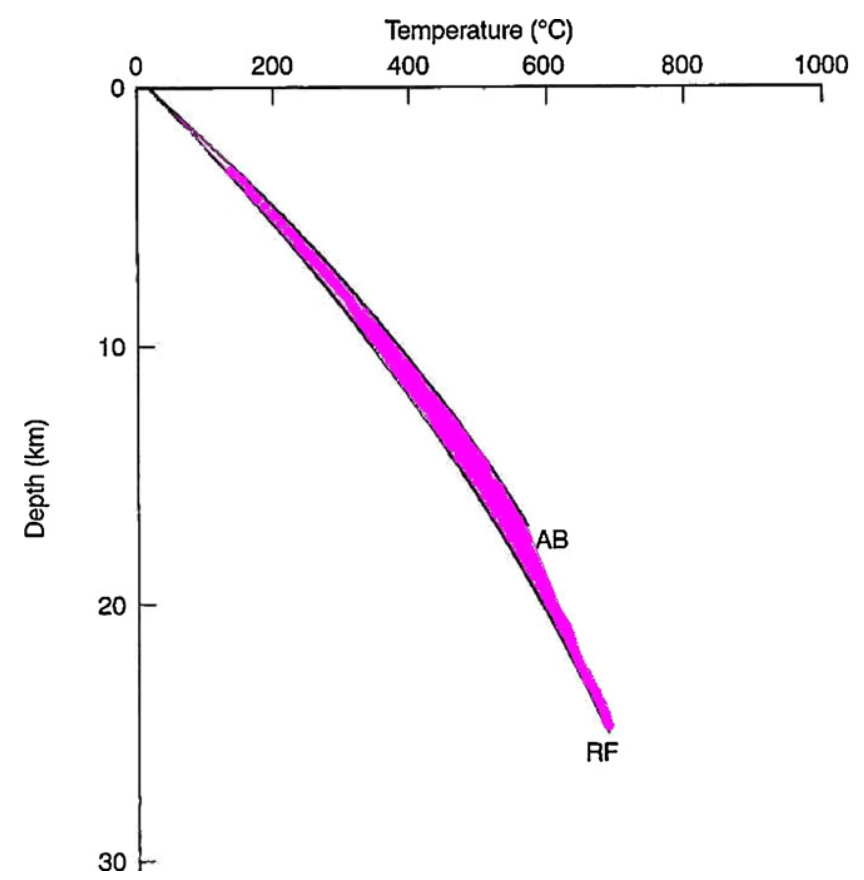

Fig. 6. Crustal geotherms beneath Eastern Rif (RF) and AlBoran basin (AB) [37].
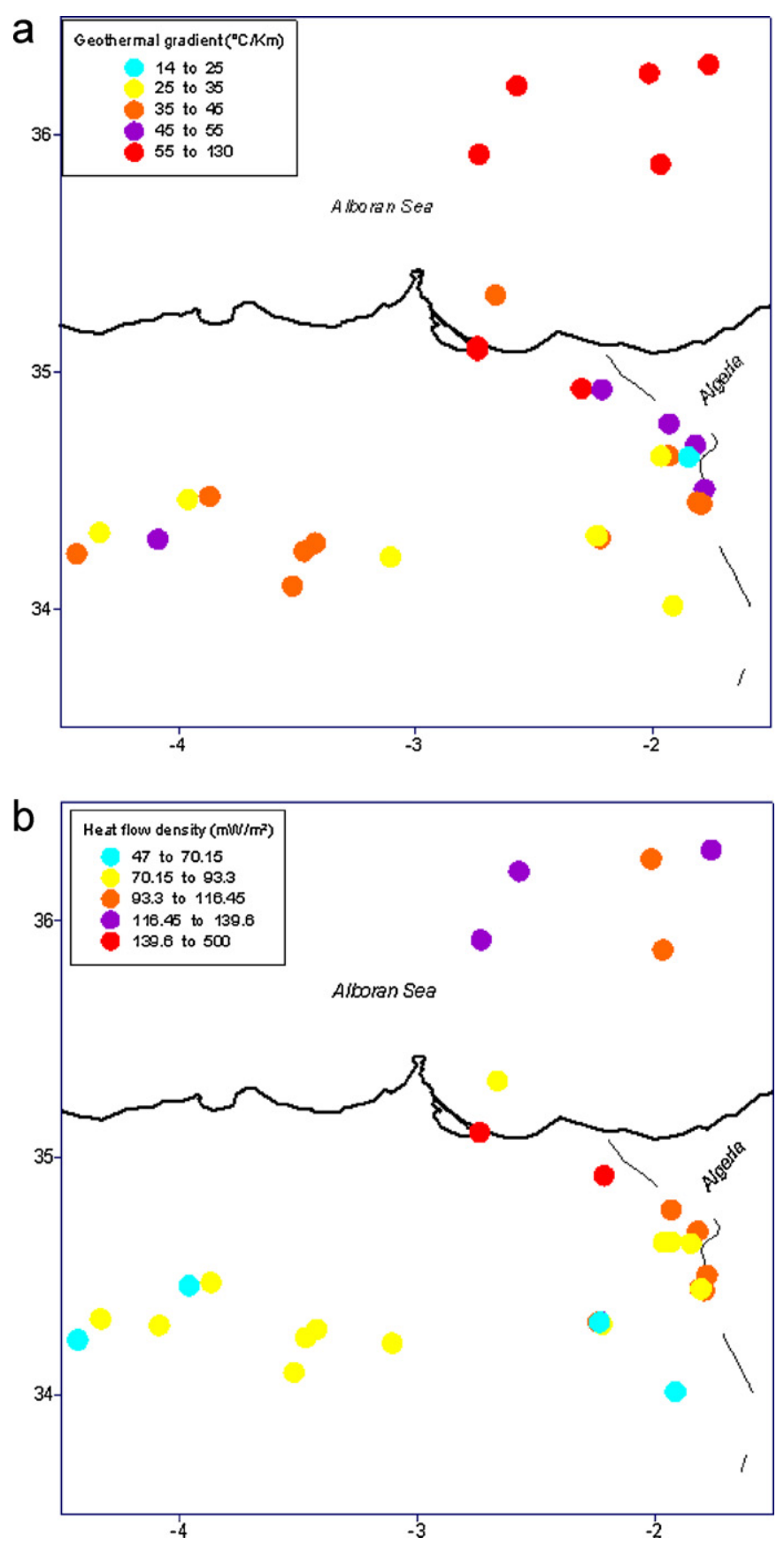

Fig. 7. Geothermal gradient (a) and Heat flow density (b) distribution in the study area.

$\Phi$ is the effective porosity, $C$ is the mean specific capacity $(\mathrm{j} / \mathrm{KgK})$, $\rho$ is the mean density of the rock column $\left(\mathrm{kg} / \mathrm{m}^{3}\right), T_{\mathrm{t}}$ is the temperature at the top of the aquifer $\left({ }^{\circ} \mathrm{C}\right), T_{0}$ the average regional temperature at the surface of the earth $\left({ }^{\circ} \mathrm{C}\right)$, a is the area of the aquifer, and $\Delta_{z}$ is the thickness of the aquifer; the subscripts $\mathrm{m}$ and $\mathrm{w}$ refer to rock matrix and water, respectively.

For the Berkane well if we assume that: $\Phi=0.1, T_{0}=20^{\circ} \mathrm{C}$, $T_{\mathrm{t}}=30^{\circ} \mathrm{C}, \quad \rho_{\mathrm{w}}=1000 \mathrm{~kg} / \mathrm{m}^{3}, \quad \rho_{\mathrm{m}}=2600 \mathrm{~kg} / \mathrm{m}^{3}, \quad C_{\mathrm{w}}=4190 \mathrm{~J} / \mathrm{kgK}$, $C_{\mathrm{m}}=840 \mathrm{~J} / \mathrm{kg} \mathrm{km}$ the heat in place per square meter is about $9.5 \times 109 \mathrm{~J} / \mathrm{m}^{2}\left(9.5 \mathrm{G} \mathrm{J} / \mathrm{m}^{2}\right)$.

It must be said that we were able to go with the temperature datalogger as deep as $900 \mathrm{~m}$ in the well; however, we were not counting that such high temperatures were reached at depths of about $500 \mathrm{~m}$ and so the temperature data logger saturated just above $50^{\circ} \mathrm{C}$. The next temperature log must then be obtained with 
a

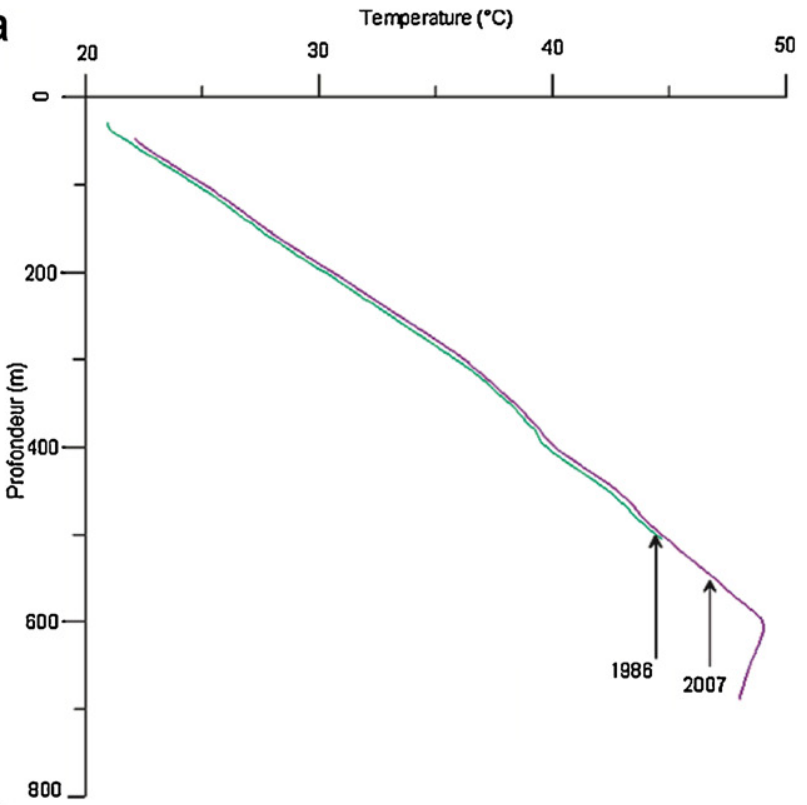

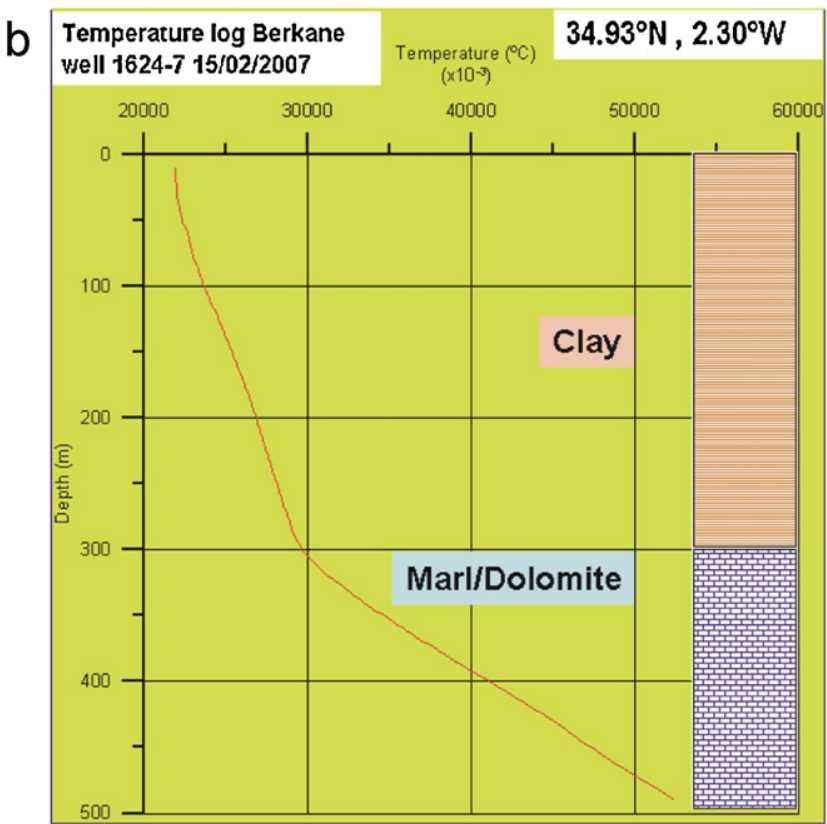

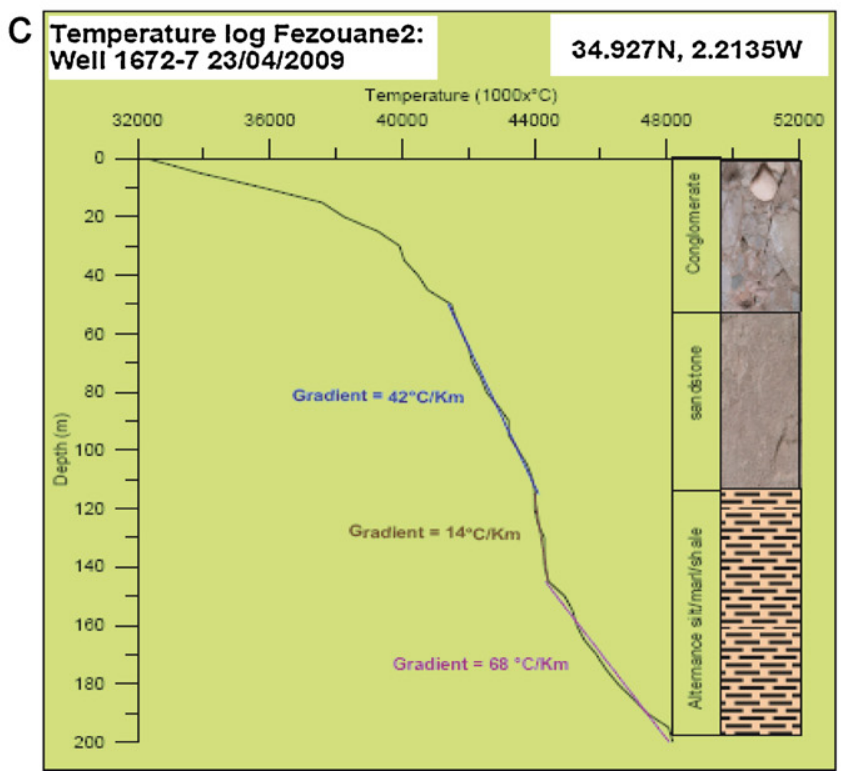

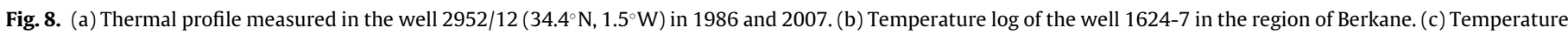
$\log$ in the well Fezouane2 in the region of Berkane.

a temperature data logger that allows measuring temperatures higher than $50^{\circ} \mathrm{C}$ or with another temperature measuring device that can measure temperatures higher than $50^{\circ} \mathrm{C}$.

\subsection{Present day thermal waters direct use in northeastern Morocco}

Tough geothermal energy research in Morocco is relatively more than forty years old [38], the utilization of geothermal resources has not yet been enough developed and still restricted to sparse low enthalpy direct uses. Among the geothermal potentialities of Morocco, numerous hot springs occur and are mostly concentrated in the northern country: Central Morocco, Prerif, and northeastern Morocco where high geothermal gradients are observed. Because of the low to intermediate enthalpy level of these geothermal hot springs, the direct use of the warm springs is still for therapeutic or for their chemical contents. However except for the spring of
Moulay Yacoub of Fez where modern therapeutic bathing exists, the thermal waters in Morocco remain still primitively used. In spite of the whole energy dependence of Morocco and the development of the geothermal studies, the Moroccan authorities are not decided yet to promote the use of the geothermal energy contained in the underground of the country which could make primarily profit it's agricultural and fishing vocation.

For a flow rate of $5 \mathrm{l} / \mathrm{s}$ and an average of $3 \mathrm{l} / \mathrm{s}$ and a temperature change of $10^{\circ} \mathrm{C}$ and a total of 12 natural spring baths (Benkachour, My Yacoub, etc.).

Installed capacity $(\mathrm{MWt})=$ peak use $\times$ “ $\Delta T " \times 0.004184$

$\times$ number of baths $=10 \mathrm{l} / \mathrm{s} \times 10^{\circ} \mathrm{C} \times 0.004184 \times 12=2.51 \mathrm{MWt}$

Annual energy use $(\mathrm{TJ} /$ year $)=$ average user “ $\Delta T$ " $\times 0.1319$

$\times$ number of baths $=3 \mathrm{l} / \mathrm{s} \times 10^{\circ} \mathrm{C} \times 0.1319 \times 12=47.48 \mathrm{TJ} /$ year 
Therefore geothermal annual used only by the natural hot baths in Morocco, remains less than 50 TJ/year which corresponds to a capacity of 3MWt.

\section{Discussion}

The new thermal logs recently recorded show possible thermal perturbation due to groundwater effects and/or water flowing within the holes. The acquired data need further processing and careful analyses before their use for geothermal modeling. However, some general conclusions can be drawn from the observed temperatures.

A change in the geothermal gradient does not appear as a result of a change in thermal conductivity. A simple calculation for the Berkane well. Fig. 8b shows that the average geothermal gradient above $300 \mathrm{~m}$ is about $29^{\circ} \mathrm{C} / \mathrm{km}$ while the geothermal gradient below $300 \mathrm{~m}$ is about $127^{\circ} \mathrm{C} / \mathrm{km}$. At a depth of about $470 \mathrm{~m}$ the temperature is $50^{\circ} \mathrm{C}$, and assuming that the same formation reaches depths of $700 \mathrm{~m}$ (see lithologic $\log$ ) this means that an estimated temperature of about $78^{\circ} \mathrm{C}$ is attained at about $700 \mathrm{~m}$.

If we assume a thermal conductivity of $1.5 \mathrm{~W} / \mathrm{m} \mathrm{K}$ for the clay above $300 \mathrm{~m}$ and a thermal conductivity of $4.0 \mathrm{~W} / \mathrm{mK}$ for the dolomites below $300 \mathrm{~m}$ we can conclude that the heat flow density along the well is not constant and therefore there is heat trapped at depth below $300 \mathrm{~m}$.

The hot water may be recovered essentially in Lias series, for geothermal purposes. However, the problem with the Liasic aquifers is that they are formed by intrinsically compact limestones and dolomites, but which can contain water in fractures and even of karsts systems. The formations may be thus transmissives but not very accumulatives which makes hardly the definition of the thickness of the aquifer, the porosity and the transmissibility. Further investigations must be deserved for a good estimation of the thickness and the porosity of the aquifer which remain key parameters for any attempt of geothermal spring assessment [39,40].

The borehole of Berkane may not be considered as representative of the geologic, hydrogeologic, and thermal status for a relatively large area, owing probably to complex upward or downward groundwater flow. We remark the difference in thermal gradient between the two boreholes, Berkane (Fig. 6) and Fezouane (Fig. 8c), between 150 and $200 \mathrm{~m}$ depth.

Notice that we were able to go with the temperature data logger as deep as $900 \mathrm{~m}$ in the well; however, at depths of about $500 \mathrm{~m}$ and so the temperature data logger has reached its maximum operation limit $\left(50^{\circ} \mathrm{C}\right)$. Future investigations should then use a temperature data logger that allows to measure temperatures higher than $50^{\circ} \mathrm{C}$.

\section{Conclusion}

It was hypothesized from geological and geophysical thermal spring data that Northeastern Morocco is likely to be a region of high average geothermal gradients and thus prospective for geothermal energy.

The heat flow measurements in hydraulic, mining and oil boreholes returned results that have validated this hypothesis.

The sediments in the study area have moderate thermal conductivity, and have been sampled for some laboratory measurements and estimated by geometric models to be between 2.5 and $7 \mathrm{~km}$ in total thickness. With this amount of moderate conductivity sediments overlying a thinned crust, plus its proximity to existing power infrastructure, the Northeastern Morocco is now considered prospective for economic geothermal energy development.

The study area is part of a larger, elongate, geographical region extending from Morocco to Alboran Sea and South-eastern Spain.

These large resources of geothermal energy in northeastern Morocco would not be unnoticed. It can be believed they will attract interest of potential investors and will be profitable also for those whole areas.

High geothermal gradients are observed in NE Morocco In the region of Berkane, temperatures higher than $50^{\circ} \mathrm{C}$ were measured in a water well at depths of about $470 \mathrm{~m}$ while this temperature was almost reached at $600 \mathrm{~m}$ in another well of Oujda region.

This large geothermal anomalies occurring at depth and this already observed in a mining borehole at Arekman area (Eastern Rif) indicate that medium to high enthalpy uses are not discarded.

Other wells are available in northeastern Morocco for temperature logging, so that the geothermal potential can be estimated. For a valuable assessment of the potential geothermal springs, detailed geophysical surveys have to be carried out in the Oujda-Berkane-Arekman area.

\section{Acknowledgements}

This work was supported by the Moroccan-French project "CNRST-CNRS SDU02/07, the Moroccan-Portuguese CNRTS-GRICES project SDT/09, the Moroccan-Italian MAE project and 7PCRD Project: “COMET" no 241400.

\section{References}

[1] Rimi A, Lucazeau F. Heat flow density measurements in northern Morocco. J Afr Earth Sci 1987;6(6):835-43.

[2] Rimi A, Chalouan A, Bahi L. Heat flow in the southernmost part of the Mediterranean alpin system, the external Rif in Morocco. Tectonophysics 1998;285:135-6.

[3] Zarhloule Y. Potentialités géothermiques du Maroc: traitement intégré par les températures profondes et indices de surface. Doctorat d'Etat, Fac Sci Oujda, Maroc (1999).

[4] Zarhloule Y, Lahrach A, Ben Aabidate L, Bouri S, Boukdir A, Khattach D, et al. La prospection géothermique de surface au Maroc: hydrodynamisme, anomalies géothermiques et indices de surface. J Afr Earth Sci 2001;32:851-67.

[5] Rimi A. Evidence of recent warming in the north of Morocco from disturbed geothermal gradients. Geodinamica Acta 2000;13(1):19-27.

[6] Zarhloule Y, Bouri S, Lahrach A, Boughriba M, Elmandour A, Ben Dhia H. Hydrostratigraphical study, geochemistry of thermal springs, shallow and deep geothermal exploration in Morocco: hydrogeothermal potentialities. In: Proceedings, World Geothermal Congress. 2005.

[7] Facca G. Les possibilités géothermiques du Maroc. Note SEGM (1968), no. 14, inédit.

[8] Alsac C, Cornet G, Destombes JP, Hentinger R, Lavigne J. Etude géothermique du Maroc oriental. Rapport inédit, BRGM 69 SGL 264 GTM, Orléans, France (1969), 97 p., 16 Fig.

[9] Cornet G, Demange J, Ducroux J, Lopoukhine M. Etude géothermique du Rif (Maroc). France: BRGM 74 SGN 087 gth; 1974, 53 p.

[10] El Hammichi F, Tabyaoui H, Chaouni A, Ait Brahim L, Chotin P. Pliocène tectonics in Moroccan Rifian Forland: coexistence of compressive and extensional structures. Rev Soc Geol Espa 2006;19:1-2.

[11] Hernàndez J, Bellon H. Chronologie K-Ar du volcanisme miocéne. Rev Geol Geogr Phys 1985;26:85-94.

[12] Bellon H. Séries magmatique néogènes et quaternaires du pourtour de la méditerranée occidental, comparées dans leur cadre géochronométrique: implication géodynamiques. Ph.D. dissert. Univ. de Paris Sud Centre D’Orsay, France (1976).

[13] Chalouan A, Michard A, El Kadiri K, Negro F, Frizon de Lamotte D, Saddiqi O. The Rif belt. In: Michard A, Chalouan A, Saddiqi O, Frizon de Lamotte D, editors. Continental evolution: the geology of Morocco. Springer; 2008. p. 203-302.

[14] Andeweg B, Cloetingh S. Evidence for an active sinistral shear zone in the western Alboran region. Terra Nova 2001;13:44-50.

[15] Zeyen H, Ayarza A, Fernandez M, Rimi A. Lithospheric structure under the western African-European plate boundary: a transect across the Atlas Mountains and the Gulf of Cadiz. Tectonics 2005;24:TC2001, doi:10.1029/2004TC001639.

[16] Missenard Y, Zeyen H, Frizon de Lamotte D, Leturmy P, Petit C, Sébrier M, et al. Crustal versus asthenospheric origin of the relief of the Atlas Mountains of Morocco. J Geophys Res 2006;111:B03401, doi:10.1029/2005JB003708.

[17] Royden LH. Evolution of retreating subduction boundaries formed during continental collision. Tectonics 1993;12:629-38.

[18] Zeck HP. Betic-Rif orogeny: subduction of Mesozoic Tethys lithosphere under eastward drifting Iberia, slab detachment shortly before $22 \mathrm{Ma}$, and subsequent uplifting and extensional tectonics. Tectonophysics 1996;254:1-16.

[19] Platt JP, Vissers RLM. Extensional collapse of thickened continental lithosphere: a working hypothesis for the Alboran Sea and Gibraltar Arc. Geology 1989;17:540-3.

[20] Seber D, Barazangi M, Tadili BA, Ramdani M, Ibenbrahim A, Ben Sari D. Threedimensional upper mantle structure beneath the intraplate Atlas and interplate Rif Mountains of Morocco. J Geophys Res 1996;101:3125-38. 
[21] Pasquale V, Verdoya $M$, Chiozzi P. Some geophysical constraints to dynamic processes in the southwestern Mediterranean. Ann Geophys 1996;39(6):1185-200.

[22] Ziegler PA. Europ Cenozoic rift system. Tectonophysics 1992;208:91-111.

[23] Lahrach A. Potentialités hydrogéothermiques du Maroc oriental. Thèse de Doctorat de spécialité, Ecole Nationale d'Ingénieurs de Sfax, Tunisie, 273 p. (1994).

[24] Ben Aabidate L. Contribution à l'étude hydrogéothermique du Maroc nord-occidental (Rharb, Rides et Saïss). Thèse de Doctorat de spécialité, Ecole Nationale d'Ingénieurs de Sfax, Tunisie, 245 p. (1994).

[25] Boukdir A. Contribution à l'étude géothermique du bassin de Tadla, Plateau des phosphates et Tassaout aval. Applicationau réservoir calcaire du Turonien. Thèse de 3ème Cycle, Univ. Cadi Ayyad, Fac Sci Marrakech, 240 p. (1994).

[26] Zarhloule Y. Potentialités hydrogéothermiques du bassin d'Essaouira-Agadir. Thèse de Doctorat de spécialité, Ecole Nationale d'Ingénieurs de Sfax, Tunisie. 239 p. (1994).

[27] Zarhloule Y. Les. Potentialités géothermiques du Maroc: Approche intégrée par les températures profondes et indices de surface. Thèse de Doctorat ès Sciences. Univ. Mohammed 1st Fac Sci Oujda, 153p. (1999).

[28] Winckel A. Etablissement d'une typologie des eaux thermals par une approche hydrochimique, isotopique et tectonique. Exemple du Maroc. PhD Thesis, Université de Paris Sud-Orsay, France (2002).

[29] Hernandez J. Le volcanisme miocène du Rif oriental (Maroc), géologie, pétrologie, minéralogie d'une province schochonitique. PhD. dissert. Univ. P. et Marie Curie. Paris, 580p. (1983).
[30] Hervouët Y. Géodynamique alpine (Trias-Actuel) de la marge septentrionale de l'Afrique au Nord du bassin de Guercif (Maroc oriental). Ph.D. dissert. Univ. Pau, France, 367p. (1985).

[31] Rimi A, Zeyen H, Zarhloule Y, Correia A, Carneiro J, Cherkaoui T. Structure de la lithosphère à travers la limite des plaques Ibérie - Afrique par modélisation intégrée de température et de densité le long d'un transect N-S à 3(Ouest. Bull Inst Sci 2008;30:29-37.

[32] Rimi A, Fernandez M, Manar A, Matsushima J, Okubo Y, Morel JL, et al. Geothermal anomalies and analysis of gravity fracturing and magnetic features in Morocco. In: World Geothermal Congress Antalya, vol. 2. 2005. p. 4-290.

[33] Fernàndez M, Marzán I, Correia A, Ramalho E. Heat flow, heat production, and lithospheric thermal regime in the Iberian Peninsula. Tectonophysics 1998;291:29-54.

[34] Polyak BG, Fernandez M, Khutoskoy MD, Soto JI, Basov IA, Comas MC et al. Heat flow in the Alboran Sea, western Mediterranean. Tectonophysics 1996;263:191-218.

[35] Rimi A, Variations régionales du flux géothermique au Maroc, application. Thèse de Doctorat ès Sciences, Univ. Mohammed V, Fac Sci Rabat, 154 p. (1999)

[36] Zarhloule Y, Rimi A, Boughriba M, Barkaoui AE, Lahrach A. The geothermal research in Morocco: history of 40 years. In: World Geothermal Congress (2010). 2010.

[37] Muffler LJP, Cataldi R. Methods for regional assessment of geothermal springs. Geothermics 1978;7:53-89.

[38] Rimi A, Correia A, Carneiro J, Verdoya M, Zarhloule Y, Lucazeau F, et al. New geothermal prospect in north-eastern morocco. In: World Geothermal Congress, 2010. 2010. 